\title{
Pengaruh Daya Tarik Wisata Terhadap Niat Berkunjung Ulang Melalui Kepuasan Wisatawan (Studi pada wisatawan "Kampung Warna Warni" di Kota Malang)
}

\author{
Mega Mirasaputri Cahyanti \\ Dosen STIE Asia \\ Jl. Borobudur No 21 Malang \\ Telp. (0341) 478494
}

\begin{abstract}
:
This research has several objectives: (1) Knowing the influence of tourist attraction to the satisfaction of tourists,(2) Knowing the effect of tourist satisfaction on the intention of repeated visit, and (3) Knowing the direct influence of tourist attraction to the intention of the visit of tourists in Kampung Warna Warni Kota Malan. This research method using quantitative approach with descriptive analysis method, data collecting technique by spreading questionnaires to 100 respondents at tourist sites and hypothesis testing method using path analysis. The result shows that: (1) The tourist attraction has a significant effect on the satisfaction of the tourists (H1 accepted), (2) The satisfaction of tourists has a significant influence on the intention of the tourist visiting in Kampung Warna Warni Malang (H2 accepted), and (3) Tourist attraction has a significant direct effect on the intention of the visit of tourists in Kampung Warna Warni Malang (H3 accepted). And the results of testing Sobel show that the variable satisfaction of tourists mediate tourist attraction and intention to revisit the Kampung Warna Warni Malang.

Keywords: Travel Attractions, Tourist Satisfaction, Tourist Visits
\end{abstract}

\section{PENDAHULUAN}

\section{Latar Belakang Masalah}

Pada tahun 2016, muncul fenomena di Kota Malang yaitu adanya destinasi wisata baru buatan masyarakat, yang disebut Kampung Wisata. Konsep dari Kampung Wisata tersebut mengusung tema kampung tematik yang mengedepankan masing-masing keunggulan sebagai produk utama dari jenis wisata tersebut. Terdapat lebih dari sepuluh kampung tematik yang berada di Kota Malang, namun hanya satu yang berhasil memperoleh pengunjung terbanyak dan dikenal oleh wisatawan lokal maupun domestik, yaitu Kampung Warna Warni.

Kampung warna warni, berlokasi di Kelurahan Jodipan dan Kecamatan Kedungkandang. Ide inovatif awal terbentuknya kampung warna-warni digagas oleh sekelompok mahasiswa dari Universitas Muhammadiyah Malang (UMM) yang bertujuan mengubah daerah kumuh menjadi daerah 
yang bersih, sehat dan bernilai ekonomis. Namun, ide yang inovatif saja tidak cukup. Dalam usaha menarik minat wisatawan, diperlukan penanganan yang profesional atas sektor pariwisata terutama untuk produk wisata sebagai daya tarik wisatawan.

Menurut Yoeti (2006), daya tarik wisata merupakan produk wisata yang merupakan objek penawaran dalam pemasaran pariwisata. Daya tarik wisata, termasuk didalamnya pariwisata yang bersumber dari alam (natural and cultural based tourism), (2) Fasilitas yang dimiliki objek wisata meliputi akomodasi, industri makanan, parkir, area rekreasi, dan (3) Kemudahan dalam mencapai objek tujuan wisata tersebut. Namun, daya tarik wisata dalam penelitian ini bersumber dari atraksi buatan manusia, yaitu desain warna-warni yang dihasilkan dari cat tembok pada masingmasing rumah di kawasan kampung tersebut.

Seiring perkembangan waktu, kini Kampung Warna Warni menjadi tempat baru bagi para wisatawan untuk menghabiskan waktu libur panjangnya. Berdasarkan informasi yang diperoleh dari Kasi Promosi Pemasaran Dinas Kebudayaan dan Pariwisata Kota Malang, Agung H. Buana menyebutkan, kunjungan di Kampung Warna Warni mengalami peningkatanyang signifikan. Data yang diperoleh menunjukan bahwa jumlah kunjungan pada hari biasa dapat mencapai $500-700$ wisatawan per hari, sedangkan pada hari libur Lebaran pengunjung dapat mencapai 2.000 wisatawan per hari. Dengan melihat banyaknya jumlah pengunjung tiap harinya, menuntut pengelola Kampung Wisata Warna Warni untuk dapat memberikan kepuasan pada wisatawan yang datang berkunjung.

Prinsip utama kepuasan wisatawan adalah perbandingan antara apa yang diharapkan dengan tingkat kinerja yang dirasakan oleh wisatawan. Artinya kepuasan itu merupakan perbandingan antara kinerja dan harapan, jika kinerja produk dirasakan lebih tinggi dari harapan, maka wisatawan akan senang dan puas. Sebaliknya jika kinerja yang dirasakan lebih rendah dari harapan maka wisatawan akan kecewa dan tidak puas (unsatisfaction) (Coban, 2012).

Menurut penelitian terdahulu, terdapat hubungan positif antara kepuasan wisatwan dengan niat kunjungan ulang wisatawan yang berarti bahwa wisatawan akan merasa terpenuhi tingkat harapannya setelah melakukan kunjungan sehingga meningkatkan komitmen pembelian untuk berkunjung kembali ke objek tujuan wisata tersebut (Rozak, 2012).

Munculnya Kampung Wisata Warna Warni yang langsung menjadi viral di media sosial dan hanya menyuguhkan daya tarik yang monoton, tidak akan 
bisa mempertahankan jumlah wisatawan yang berkunjung apabila tidak memperhatikan kepuasan wisatawan dan melakukan upaya terhadap wisatawan untuk mau melakukan kunjungan ulang. Wisatawan yang memiliki niat untuk melakukan kunjungan ulang akan sangat logis untuk merekomendasikan destinasi wisata, sementara wisatawan yang bersedia merekomendasikan destinasi belum tentu akan melakukan kunjungan ulang ke destinasi wisata tersebut (Ahmad dan Badarneh, 2011).Walaupun belum dapat dipastikan apakah wisatawan yang memiliki niat berkunjung ulang merasakan kepuasan terhadap daya tarik Kampung Warna Warni.

Dengan demikian, masih terdapat pertanyaan yang belum terjawab apakah daya tarik yang saat ini dimiliki oleh Kampung Warna Warni dapat membuat wisatawan memiliki niat untuk berkunjung kembali setelah merasakan kepuasan. Meskipun terdapat banyak penelitian yang membahas mengenai niat berkunjung kembali, namun belum ada penelitian ilmiah yang mempelajari tingkatan kepuasan pelanggan dan niat untuk berkunjung ulang pada jenis pariwisata dengan konsep baru yang disebut dengan kampung tematik yaitu Kampung Warna Warni di Kota Malang.

\section{Rumusan Masalah}

Berdasarkan latar belakang tersebut maka peneliti merumuskan masalah sebagai berikut: (1) Apakah terdapat pengaruh antara daya tarik wisata terhadap kepuasan wisatawan di Kampung Warna Warni?; (2) Apakah terdapat pengaruh antara kepuasan wisatawan terhadap niat berkunjung ulang wisatawan di Kampung Warna Warni?; dan (3) Apakah terdapat pengaruh antara daya tarik wisata terhadap niat berkunjung ulang wisatawan di Kampung Warna Warni?

\section{TINJAUAN PUSTAKA}

\section{Daya Tarik Wisata}

Daya tarik wisata termasuk dalam produk wisata, dengan kata lain sebuah atraksi yang diberikan oleh tujuan wisata yang diharapkan oleh pengelola dapat dinikmati oleh wisatawan. Konsep tersebut sesuai dengan pengertian daya tarik wisata pada penelitian terdahulu, yang diungkapkan oleh Ali (2012), bahwa daya tarik wisata merupakan produk wisata dalam suatu kesatuan tidak hanya keindahan alam dari destinasi tersebut, tetapi meliputi atribut lainnya seperti daya tarik, fasilitas dalam saat berwisata, dan juga akses menuju tempat wisata tersebut.

Berdasarkan Basiya dan Rozak (2012), terdapat motivasi utama bagi para pengunjung untuk melakukan kunjungan wisata yaitu daya tarik destinasi. Destinasi wisata dapat dikelompokan menjadi empat daya tarik, diantaranya adalah: (1) Daya tarik wisata alam (natural attraction) yang meliputi pemandangan alam daratan, pemandangan alam lautan, pantai, iklim atau 
cuaca; (2) Daya tarik wisata berupa arsitektur bangunan (building attraction) yang meliputi bangunan dan arsitektur bersejarah, bangunan dan arsitektur modern, arkeologi; (3) Daya tarik wisata yang dikelola khusus (managed visitor attractions), yang meliputi tempat peninggalan kawasan industri; (4) Daya tarik wisata budaya (cultural attraction) yang meliputi teater, musium, tempat bersejaah, adat-istiadat, tempat-tempat religius, peristiwa-peristiwa khusus seperti festival dan drama bersejarah (pageants), dan heritage seperti warisan peninggalan budaya; dan (5) Daya tarik wisata sosial seperti gaya hidup penduduk di tempat tujuan wisata. Elemen-elemen daya tarik tempat tujuan wisata merupakan pilihan pengunjung dan yang mendorong bagi pengunjung untuk melakukan kunjungan wisata. Dalam penelitian ini, daya tarik yang dimiliki oleh kampung warna warni tergolong pada daya tarik yang dikelola khusus dari tempat yang sebelumnya bukan merupakan tujuan wisata menjadi daerah tujuan wisata.

\section{Kepuasan Wisatawan}

Menurut Simamora (2006) Kepuasan Pelanggan adalah hasil pengalaman terhadap produk atau jasa, ini merupakan sebuah perasaan pelanggan setelah membandingkan antara harapan (Prepurchase Expectation) dengan kinerja aktual (Actual Performance). Berdasarkan definisi di atas dapat disimpulkan bahwa kepuasan merupakan fungsi dari kesan kinerja dan harapan, jika kinerja sama dengan harapan maka wisatawan akan merasa puas. Kepuasan wisatawan dapat memberikan beberapa manfaat menurut Assael (2007) di antaranya: (1) Hubungan antara wisatawan dan host destinasi wisata akan harmonis; (2) Memberikan alasan yang baik untuk melakukan pembelian ulang; (3) Terciptanya loyalitas wisatawan dan membentuk rekomendasi destinasi wisata secara word of mouth kepada masyarakat luas; dan (4) Kepuasan wisatawan juga memperkuat prilaku terhadap merek dan kemungkinan besar konsumen akan menggunakan merek yang sama pada masa yang akan datang.

\section{Niat untuk Berkunjung Ulang}

Berdasarkan pendapat dari Assael (2007) dimana manfaat dari kepuasan wisatawan di antaranya adalah kemungkinan besar mereka menggunakan merk yang sama di masa depan, maka niat berkunjung ulang merupakan definisi lain dari adanya kemungkinan yang besar dalam penggunaan kembali merk yang sama. Menurut Parasuraman, Zeitami dan Berry dalam penelitian yang dilakukan oleh Fue Zeng, Zuohao $\mathrm{Hu}$, Rong Chen dan Zhilin Yang (2009), Repurchase Intention, suatu niat berprilaku yang mendorong wisatawan untuk melakukan kunjungan ulang ke suatu destinasi wisata dalam kurun waktu tertentu.

Dalam penelitian ini, objek penelitian yang digunakan adalah jenis usaha yang menawarkan jasa pariwisata, maka istilah repurchase intention dapat 
diubah menjadi revisit intention. Merujuk pada pengertian intention bahwa pengukuran yang dilakukan dalam penelitian ini adalah hanya terbatas pada keinginan atau niat yang dimiliki wisatawan untuk melakukan kunjungan setelah mereka mengunjungi kampung wisata.

\section{KERANGKA KONSEPTUAL DAN HIPOTESIS}

Berikut ini adalah gambar bagan kerangka konseptual penelitian ini, dimana diduga variabel bebas mempengaruhi variabel terikat.

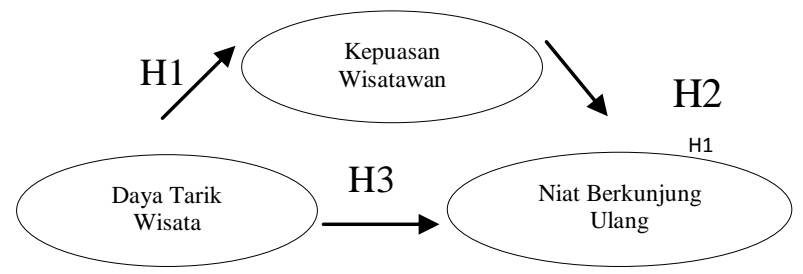

\section{Gambar 1. Kerangka Penelitian}

Adapun hipotesis-hipotesis yang diambil dalam penelitian ini antara lain:

$\mathrm{H}_{1}$ : Terdapat pengaruh yang signifikan antara daya tarik wisata terhadap kepuasan wisatawan di Kampung Warna Warni

$\mathrm{H}_{2}$ : Terdapat pengaruh yang signifikan antara kepuasan wisatawan terhadap niat berkunjung ulang wisatawan di Kampung Warna Warni

$\mathrm{H}_{3}$ : Terdapat pengaruhlangsung yang signifikan antara daya tarik wisata terhadap niat berkunjung ulang wisatawan di Kampung Warna Warni

\section{METODOLOGI PENELITIAN}

Penelitian ini menggunakan pendekatan kuantitatif dan jenis penelitian analisis deskriptif dengan jumlah populasi yang tidak dapat diketahui. Tekhnik pengambilan sampel dalam penelitian ini yaitu non-probability sampling, dengan tekhnik accidental sampling yaitu peneliti memilih sampel berdasarkan ketersediaan dan kesediaan subjek yang pada saat itu ditemui oleh peneliti, serta tentu saja wisatawan yang bersedia mengisi kuesioner. Banyaknya target sampel adalah 100 responden, dengan jangka waktu selama satu minggu dari tanggal 8 - 15 Januari 2018. Tehnik pengumpulan data dengan menyebarkan kuesioner yang berbentuk skala likert. Tehnik pengujian data mengunakan uji validitas dan uji reliabiltas kuesioner, dilanjutkan dengan uji analisis data menggunakan analisis jalur (path analysis) yang melalui dua tahap yaitu: uji regresi linier sederhana dan uji regresi linier berganda serta uji Sobel.

Tabel 1. Definisi Operasional Variabel

\begin{tabular}{cl}
\hline Variabel & \multicolumn{1}{c}{ Items } \\
\hline Daya Tarik & $\begin{array}{l}\text { Konsep yang ditawarkan di Kampung Wisata Tridi menarik } \\
\text { Wisata }\end{array}$ \\
\cline { 2 - 2 } (Ali, 2012) & Akses menuju Kampung Wisata Tridi dapat dijangkau dengan \\
\hline
\end{tabular}




\begin{tabular}{|c|c|}
\hline & kendaraan apapun \\
\hline & $\begin{array}{l}\text { Harga tiket masuk yang ditawarkan sesuai dengan keindahan } \\
\text { yang ditawarkan }\end{array}$ \\
\hline \multirow{5}{*}{$\begin{array}{c}\text { Kepuasan } \\
\text { Wisatawan } \\
\text { (Taylor dan } \\
\text { Baker, 1994) }\end{array}$} & Berdasarkan pengalaman, wisatawan merasa senang berkunjung \\
\hline & ke kampung warna warni. \\
\hline & Kampung warna warni telah memenuhi harapan wisatawan \\
\hline & $\begin{array}{l}\text { Wisatawan percaya bahwa berkunjung ke kampung warna warni } \\
\text { merupakan pengalaman yang memuaskan }\end{array}$ \\
\hline & $\begin{array}{l}\text { Secara keseluruhan, wisatawan percaya, kampung warna warni } \\
\text { menyenangkan hati wisatawan ketika berkunjung kesana. }\end{array}$ \\
\hline \multirow{3}{*}{$\begin{array}{c}\text { Niat } \\
\text { Berkunjung } \\
\text { Ulang } \\
\text { (Kabadayan } \\
\text { dan Alan, } \\
\text { 2012) \& } \\
\text { (Nurlestari, } \\
\text { 2016) }\end{array}$} & $\begin{array}{l}\text { Saya akan merekomendasikan kampung warna warni kepada } \\
\text { teman atau keluarga }\end{array}$ \\
\hline & $\begin{array}{l}\text { Saya memiliki niat yang kuat untuk mengajak keluarga ke } \\
\text { kampung warna warni }\end{array}$ \\
\hline & Saya bersedia untuk berkunjung kembali dalam waktu dekat \\
\hline
\end{tabular}

\section{HASIL DAN PEMBAHASAN}

Pemenuhan Asumsi

Nilai signifikansi pada tabel Kolmogorov-Smirnov Test menunjukan nilai yang bervariasi antara $0,052-0,054$, untuk variabel $\mathrm{X}, \mathrm{Z}$ dan $\mathrm{Y}$, dimana semuanya memiliki nilai yang lebih besar dari 0,05 , sehingga dapat disimpulkan bahwa semua data pada setiap variabel telah terdistribusi secara normal. Nilai VIF semua variabel bebas dalam tabel Coefficients dalam output SPSS menunjukan angka kurang dari 10 yang berarti tidak terjadi multikolinearitas. Hasil uji Gletser untuk Heteroskedastisitas menunjukkan nilai signifikansi pada tabel Coefficients dari hasil regresi $X, Z$ terhadap Residual 2 (nilai absolut dari residual regresi X,Z - Y) di atas 0,05, maka tidak terdapat heteroskedastisitas.

\section{Uji Instrumen Data}

Sebanyak 100 data hasil kuesioner dari sampel yang dipilih dalam penelitian ini telah memenuhi uji validitas dengan nilai Pearson Corellation bervariasi antara 0,905 - 0,936. Sedangkan nilai Cronbach's Alpha sebesar 0,858 0,919 memenuhi asumsi di atas 0,6 sehingga kuesioner reliabel. Demikian juga pemenuhan uji asumsi klasik normalitas dengan hasil Sig. pada tabel Kolomogorvv Smirnoff dari tiga variabel berturut-turut sebesar 0,054;0,052;0,053 lebih besar dari 0,05. Selain itu, hasil uji Multikolinearitas menunjukkan nilai VIF (2,292 dan 2,292) dari ketiga variabel < 10, dan nilai Tolerance $(0,436$ dan 0,436) >0,1 memenuhi asumsi tidak terjadi Multikolinearitas. Berdasarkan hasil ujiGlejser, nilai signifikansi (Sig.) > 0,05 maka tidak terjadi gejala Heteroskedastisitas. 


\section{Analisis jalur (path analysis)}

Menurut Muhidin dan Abdurahman (2007) dalam Nadya (2012) pada dasarnya analisis jalur digunakan untuk mengetahui hubungan antar variabel guna mengetahui pengaruh langsung maupun pengaruh tidak langsung antara variabel bebas (independent variable) terhadap variable terikat (dependent variable). Path analysis dilakukan dengan dua tahap uji hipotesis yaitu : uji regresi linier sederhana dan uji regresi linier berganda.

\section{Regresi Tahap 1}

Model Summary ${ }^{\mathrm{D}}$

\begin{tabular}{|l|l|r|r|r|}
\hline Model & $\mathrm{R}$ & $\begin{array}{c}\mathrm{R} \\
\text { Square }\end{array}$ & $\begin{array}{c}\text { Adjusted R } \\
\text { Square }\end{array}$ & $\begin{array}{c}\text { Std. Error of } \\
\text { the Estimate }\end{array}$ \\
\hline 1 &, $751^{\mathrm{a}}$ &, 564 &, 559 & 1,569 \\
\hline
\end{tabular}

a. Predictors: (Constant), $\mathrm{X}$

b. Dependent Variable: $Z$

ANOVA $^{\mathrm{a}}$

\begin{tabular}{|c|c|c|c|c|c|}
\hline Model & Sum of Squares & $\mathrm{df}$ & Mean Square & $\mathrm{F}$ & Sig. \\
\hline 1 Regression & 311,559 & 1 & 311,559 & 126,592 &, $000^{\circ}$ \\
\hline Residual & 241,191 & 98 & 2,461 & & \\
\hline Total & 552,750 & 99 & & & \\
\hline
\end{tabular}

a. Dependent Variable: Z

b. Predictors: (Constant), $X$

Coefficients $^{a}$

\begin{tabular}{|c|c|c|c|c|c|c|c|}
\hline \multirow[b]{2}{*}{ Model } & \multicolumn{2}{|c|}{$\begin{array}{c}\text { Unstandardized } \\
\text { Coefficients }\end{array}$} & \multirow{2}{*}{$\begin{array}{c}\begin{array}{c}\text { Standardized } \\
\text { Coefficients }\end{array} \\
\text { Beta }\end{array}$} & \multirow[b]{2}{*}{. } & \multirow[b]{2}{*}{ Sig. } & \multicolumn{2}{|c|}{$\begin{array}{c}\text { Collinearity } \\
\text { Statistics }\end{array}$} \\
\hline & $\mathrm{B}$ & Std. Error & & & & Tolerance & VIF \\
\hline $\begin{array}{ll}1 & \text { (Constant } \\
\mathrm{X}\end{array}$ & $\begin{array}{r}7,153 \\
, 761\end{array}$ & $\begin{array}{l}, 719 \\
, 068\end{array}$ & ,751 & $\begin{array}{r}9,947 \\
11,25 \\
1\end{array}$ & $\begin{array}{l}, 000 \\
, 000\end{array}$ & 1,000 & 1,000 \\
\hline
\end{tabular}

a. Dependent Variable: Z

Berdasarkan output regresi tahap 1 di atas, diketahui nilai R-Square sebesar 0,564 , artinya $56,4 \%$ kepuasan wisatawan dipengaruhi olehdaya tarik wisata. Uji $F$ berdasarkan nilai $F$ atau Sig. pada Tabel ANOVA menunjukkan bahwa model regresi memenuhi goodness of fit atau model regresi yang terbentuk dapat digunakan untuk memprediksi variabel independen. Uji $\mathrm{t}$ berdasarkan nilai $\mathrm{t}$ atau Sig. pada Tabel Coefficient menunjukkan bahwa daya tarik wisata berpengaruh signifikan terhadap kepuasan wisatawan. 
Regresi Tahap II

Model Summary ${ }^{\mathrm{D}}$

\begin{tabular}{|l|c|r|r|r|}
\hline Model & $\mathrm{R}$ & $\begin{array}{c}\mathrm{R} \\
\text { Square }\end{array}$ & $\begin{array}{c}\text { Adjusted } \mathrm{R} \\
\text { Square }\end{array}$ & $\begin{array}{c}\text { Std. Error of } \\
\text { the Estimate }\end{array}$ \\
\hline 1 &, $872^{\mathrm{a}}$ &, 761 &, 756 & 1,133 \\
\hline
\end{tabular}

a. Predictors: (Constant), Z, X

b. Dependent Variable: $Y$

ANOVA $^{\mathrm{a}}$

\begin{tabular}{|c|c|c|c|c|c|c|}
\hline & & $\begin{array}{c}\text { Sum of } \\
\text { Squares }\end{array}$ & $\mathrm{df}$ & $\begin{array}{c}\text { Mean } \\
\text { Square }\end{array}$ & $\mathrm{F}$ & Sig. \\
\hline \multirow[t]{3}{*}{1} & Regression & 396,455 & 2 & \multirow{3}{*}{$\begin{array}{r}198,228 \\
1,284\end{array}$} & \multirow[t]{3}{*}{154,399} & \multirow[t]{3}{*}{, $000^{6}$} \\
\hline & Residual & 124,535 & 97 & & & \\
\hline & Total & 520,990 & 99 & & & \\
\hline
\end{tabular}

a. Dependent Variable: $Y$

b. Predictors: (Constant), Z, X

Coefficients $^{\mathrm{a}}$

\begin{tabular}{|c|c|c|c|c|c|c|c|}
\hline \multirow[b]{2}{*}{ Model } & \multicolumn{2}{|c|}{$\begin{array}{c}\text { Unstandardized } \\
\text { Coefficients }\end{array}$} & \multirow{2}{*}{$\begin{array}{c}\begin{array}{c}\text { Standardiz } \\
\text { ed } \\
\text { Coefficient } \\
\mathrm{s}\end{array} \\
\text { Beta }\end{array}$} & \multirow[b]{2}{*}{$t$} & \multirow[b]{2}{*}{ Sig. } & \multicolumn{2}{|c|}{$\begin{array}{l}\text { Collinearity } \\
\text { Statistics }\end{array}$} \\
\hline & $B$ & Std. Error & & & & $\begin{array}{c}\text { Toleran } \\
\text { ce }\end{array}$ & VIF \\
\hline $\begin{array}{ll}1 & \text { (Consta } \\
\text { nt) }\end{array}$ & $-2,201$ & ,736 & & $-2,989$ & ,004 & & \\
\hline$x$ & 293 & ,074 & 298 & 3,965 & ,000 & ,436 & 2,292 \\
\hline Z & ,608 & ,073 & ,626 & 8,331 & ,000 & ,436 & 2,292 \\
\hline
\end{tabular}

a. Dependent Variable: $Y$

Berdasarkan output regresi tahap 2 di atas, diketahui nilai R-Square sebesar 0,761 , artinya $76,1 \%$ niat berkunjung ulang dipengaruhi oleh daya tarik wisata dan kepuasan wisatawan. Uji F berdasarkan nilai F atau Sig. pada Tabel ANOVA menunjukkan bahwa model regresi memenuhi goodness of fit. Uji $\mathrm{t}$ berdasarkan nilai $\mathrm{t}$ atau Sig. pada Tabel Coefficient menunjukkan bahwa daya tarik wisaya berpengaruh signifikan terhadap niat berkunjung ulang, sedangkan kepuasan wisatawan berpengaruh signifikan terhadap niat berkunjung ulang.

Berdasarkan nilai Beta dalam kedua Tabel Coefficient di atas, dapat ditentukan nilai koeffisien setiap path (jalur) sebagai berikut:

$$
\rho z x=0,751 ; \rho y z=0,626 ; \rho y x=0,298
$$

Dengan Model Regresi Analisis Jalur:

$\mathrm{Z}=7,153+0,751 \mathrm{X}+\varepsilon$

$\mathrm{Y}=-2,201+0,298 \mathrm{X}+0,626 \mathrm{Z}+\varepsilon$

\section{Pengaruh Total Xterhadap Y melalui Z :}


Pengaruh Langsung $=\mathrm{pYX} 1=0,298$

Pengaruh Tidak Langsung $=\rho z x * \rho y z=0,751 * 0,626=0,470$

Pengaruh Total $=0,768$

\section{Uji Sobel}

Uji ini dilakukan dengan cara menghitung nilai z dari sobel test yang dapat memanfaatkan online kalkulator di www.danielsoper.com. Cara menggunakan online kalkulator pada web tersebut adalah: masukkan nilai koefisien regresi daya tarik wisata terhadap kepuasan wisatawan $=0,751 \mathrm{di}$ kolom A, nilai koefisien regresi kepuasan wisatawan terhadap niat berkunjung ulang $=0,626$ pada kolom $B$. Nilai standar error pengaruh daya tarik wisata ke kepuasan wisatawan pada kolom SEA $=0.068$ dan nilai standar eror pengaruh kepuasan wisatawan ke niat berkunjung ulang pada kolom SEB $=$ 0.073. Dari hasil perhitungan di atas diperoleh Nilai Sobel test statistic $=6,773>$ Nilai Z-Score $(1,96)$ untuk taraf sign. 0,05 .

\section{PEMBAHASAN}

Berdasarkan analisis statistik yang telah dilakukan terhadap masing-masing variabel yaitu variabel daya tarik wisata, variabel kepuasan wisatawan dan variabel niat berkunjung ulang wisatawan, maka peneliti menggambarkan kedalam model struktural analisis jalur sebagai berikut :

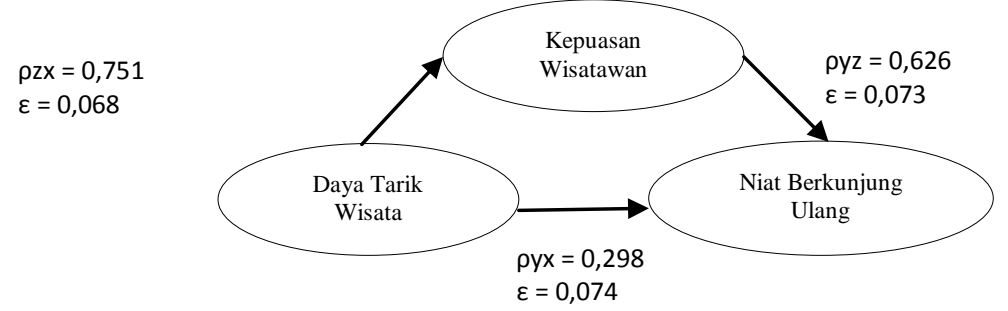

\section{Gambar 2. Model Struktural Hasil Analisis Jalur}

Dari gambar di atas dapat dilihat bahwa nilai standardized Coefficients hubungan antara tiga variabel di atas dapat dijelaskan sebagai berikut :

$\mathrm{H}_{1}=$ Pengaruh Daya Tarik Wisata (X1) terhadap Kepuasan Wisatawan (Z) memiliki nilai standardized Coefficients sebesar 0,751

$\mathrm{H}_{2}=$ Pengaruh Kepuasan Wisatawan (Z) terhadap Niat Berkunjung Ulang Wisatawan (Y) memiliki nilai standardized Coefficients sebesar 0,626

$\mathrm{H}_{3}=$ Pengaruh langsung antara Daya Tarik Wisata (X1) terhadap Niat Berkunjung Ulang Wisatawan (Y) memiliki nilai standardized Coefficients sebesar 0,298 
Adapun pengaruh tidak langsung yang dilihat dari variabel daya tarik wisata (X) terhadap niat kunjungan ulang wisatawan (Y) melalui kepuasan wisatawan $(Z)$ sebagai variabel intervening menghasilkan nilai standardized Coefficients dari hasil perkalian $0,751 * 0,626$ sebesar 0,470 .

\section{SIMPULAN}

Simpulan penelitian ini antara lain: (1) Pada pengukuran variabel daya tarik wisata terhadap kepuasan wisatawan didapatkan hasil bahwa Ho ditolak dan H1 diterima dan menjelaskan bahwa daya tarik wisata berpengaruh signifikan terhadap kepuasan wisatawan di Kampung Warna Warni Kota Malang; (2) Pada pengukuran variabel kepuasan wisatawan terhadap niat berkunjung ulang didapatkan hasil bahwa Ho ditolak dan $\mathrm{H} 2$ diterima, hal ini menjelaskan bahwa kepuasan wisatawan memiliki pengaruh signifikan terhadap niat kunjungan ulang wisatawan di Kampung Warna Warni Kota Malang; (3) Pada pengukuran variabel daya tarik wisata terhadap niat berkunjung ulang didapatkan hasil Ho ditolak dan $\mathrm{H} 3$ diterima, hal ini menjelaskan bahwa daya tarik wisata memiliki pengaruh langsung yang signifikan terhadap niat berkunjung ulang wisatawan diKampung Warna Warni Kota Malang; (4) Pengaruh tidak langsung daya tarik wisata terhadap niat berkunjung ulang lebih kuat pengaruhnya dibandingkan pengaruh langsung antara daya tarik terhadap niat berkunjung ulang di Kampung Warna Warni di Malang; dan (5) Kepuasan wisatawan mampu memediasi hubungan pengaruh daya tarik wisata terhadap niat berkunjung ulang.

\section{DAFTAR PUSTAKA}

Abdurahman M. (2007). Analisis Korelasi, Regresi dan Jalur dalam Penelitian. Bandung: CV Pustaka Setia.

Ahmad dan Badarneh, M. (2011). Tourist Satisfaction and Repeater Visitation; new comprehenshive model. International Journal of Human and Social Sciences, 38-45.

Ali, H. (2012). Pemasaran Pariwisata. Yogyakarta

Assael. (2007). Consumer Behavior and Marketing Action Edisi 3. Boston Massachusset AS: Kent Publishing Company.

Basiya R dan Hasan Abdul Rozak. (2012). Kualitas Daya Tarik Wisata, Kepuasan dan Niat Kunjungan Kembali Wisatawan Mancanegara ke Jawa Tengah. Dinamika Kepariwisataan V1. X1 No. 2.

Coban, S. (2012). The Effects of the Image of Destination on Tourist Satisfaction and Loyality : The Case of Cappadocia.

Fue Zeng, C. R. (2009). Examining Structural Relationship of Destination Image, Tourist Satisfaction and Destination Loyality. An Integrated Approach Tourism Management, 624.

Rozak, B. R. (2012). Kualitas Daya Tarik Wisata, Kepuasan Wisatawan dan Niat Kunjungan 
Kembali Wisatawan Mancanegara di Jawa Tengah. Dinamika Kepariwisataan Vol XI No.2.

Simamora, H. (2006). Managemen Sumber Daya Manusia Edisi 2. Yogyakarta: STIE YKPN.

Yoeti, A. (2006). Pengantar Ilmu Pariwisata. Jakarta. 